Jurnal Riset Biologi dan Aplikasinya
https://journal.unesa.ac.id/index.php/risetbiologi

\title{
Keanekaragaman dan Kelimpahan Jenis Burung di Kawasan Cagar Alam Besowo Gadungan dan sekitarnya Kabupaten Kediri Jawa Timur
}

\author{
Diversity and Abundance of Birds in Cagar Alam Besowo Gadungan \\ and Its Surrounding Kediri Regency, East Java Province \\ Eka Yosida Wulandari, Sunu Kuntjoro* \\ Jurusan Biologi, Fakultas Matematika dan Ilmu Pengetahuan Alam, Universitas Negeri Surabaya
}

\section{History Article}

Received: 26 Juli 2018

Approved: 2 Januari 2019

Published: Maret 2019

Kata Kunci:

keanekaragaman; kelimpahan; Cagar Alam Besowo, Burung

Key Words:

Diversity, abundance, Cagar Alam Besowo, Birds

\begin{abstract}
Abstrak
Cagar Alam Besowo Gadungan yang terletak di Kabupaten Kediri merupakan salah satu dari delapan belas wilayah cagar alam yang ada di provinsi Jawa Timur. Cagar alam ini termasuk dalam kawasan konservasi dengan tipe ekosistem hutan hujan tropis daratan rendah. Tujuan penelitian ini adalah mengevaluasi tingkat keanekaragaman, menganalisis kelimpahan jenis burung dan mengevaluasi daya dukung lingkungan di kawasan Cagar Alam Besowo Gadungan dan sekitarnya. Metode yang digunakan adalah jalur transek dengan menentukan lima stasiun pengamatan. Pengambilan data dilakukan enam kali pada bulan Maret 2018 serta dua kali pengamatan yaitu pagi dan sore pukul 07.00-10.00 WIB dan 14.00-17.00 WIB. Burung yang dijumpai diidenitifikasi berdasarkan ciri morfologi dan jumlah. Data dianalisis berdasarkan indeks keanekragaman Shannon-Wienner dan kelimpahan relatif. Hasil penelitian menunjukkan kawasan Cagar Alam Besowo Gadungan terdapat 38 jenis burung dengan indeks keanekeragaman 2,64 kategori sedang. Jenis yang paling melimpah adalah Collocalia linchi (38,20\%), Pycnonotus aurigaster (10,11\%) dan Pericrocotus cinnamomeus (5,62\%). Vegetasi yang mendukung keberadaan burung pada kawasan ini adalah Albizia chinensis, Aleurites moluccanus, Alstonia scholaris, Altingia excelsa, Coffea arabica, Hopea odorata, Ficus annulata, Ficus benjamina dan Pinus merkusii. Faktor fisik yang mendukung kehadiran burung pada pagi hari hingga sore hari suhu rata-rata $25,9-28,9^{\circ} \mathrm{C}$; kecerahan sebesar 1833,77-2279,68 Lux dan kelembaban udara 56,23-60,97\%.
\end{abstract}

\begin{abstract}
Cagar Alam Besowo Gadungan Kediri regency is one of eighteen existing nature reserves in East Java province. This nature reserve belongs to a conservation area with a lowland tropical rainforest ecosystem type. The purposes of this study were to evaluate the level of diversity, analyze the abundance of bird species, and evaluate the carrying capacity of the environment in Cagar Alam Besowo Gadungan and its surrounding areas. The method used in this research was the transect line at five observation stations. The data were collected six times during March 2018 and two observations were morning and afternoon at 07.00-10.00 WIB and 14.00-17.00 WIB. Birds encountered were identified by morphological features and numbers. Data were analyzed based on Shannon-Wienner's diversity index and relative abundance. The result of research showed that Cagar Alam Besowo Gadungan area there are 38 species of birds with 2.64 index of moderate category. The most abundant species of birds were Collocalia linchi, Pycnonotus aurigaster and Pericrocotus cinnamomeus; the relative abundace were $38.20 \%, 10.11 \%, 5.62 \%$ respectively. The vegetation that supports birds in this region are Albizia chinensis, Aleurites moluccanus, Alstonia scholaris, Altingia excelsa, Coffea arabica, Hopea odorata, Ficus annulata, Ficus benjamina and Pinus merkusii. The physical factors that support the presence of birds in the morning to late afternoon temperatures average $25.9-28.9^{\circ} \mathrm{C}$; brightness of $1833.77-$ 2279.68 Lux and air humidity 56.23-60.97\%.
\end{abstract}

How to cite: Wulandari, Y.E \& Kuntjoro, S. (2019). Keanekaragaman dan Kelimpahan Jenis Burung di Kawasan Cagar Alam Besowo Gadungan dan sekitarnya Kabupaten Kediri Jawa Timur. Jurnal Riset Biologi dan Aplikasinya. 1 (1): 18-25.

巴* Correspondence Author:

Jalan Ketintang Gedung C3 Lt. 2 Surabaya 60231, Indonesia

e-ISSN: 2655-9927

E-mail: sunukuntjoro@unesa.ac.id 


\section{PENDAHULUAN}

Kawasan Cagar Alam Besowo Gadungan merupakan kawasan konservasi yang dikelola oleh BKSDA Jawa Timur dengan tipe hutan hujan tropis dataran rendah. Jenis flora yang ditemukan pada cagar alam ini antara lain cembirit (Ervatamia divaricata), kemiri (Aleurites moluccana), pule (Alstonia scholaris) dan rau (Dracontomelon puberulum). Selain itu terdapat beberapa jenis fauna seperti babi hutan (Sus scrofa), kelelawar (Pteropus vampirus), musang (Paguma larvata) dan tupai (Sciuvus notakas). Fauna lain yang sering ditemukan pada lokasi tersebut adalah burung (BBKSDA Jatim, 2018).

Keanekaragaman dan kelimpahan jenis burung dapat menunjukkan sebagai salah satu indikator suatu kawasan. Burung menjadi salah satu indikator keanekaragaman hayati karena burung memiliki beberapa perilaku atau kebiasaan yang mendukung yaitu burung mempunyai berbagai habitat yang terletak di seluruh dunia dan burung memiliki kepekaan terhadap perubahan yang terjadi pada lingkungannya (Fitri dkk, 2015). Keberadaan burung dapat menunjukkan bahwa ekosistem tersebut masih memiliki ekosistem yang baik. Penurunan kualitas lingkungan dapat mengganggu kelangsungan hidup burung (Safanah dkk, 2017). Pengelolaan ekosistem cagar alam yang baik dapat menunjang stabilitas iklim (Sutarno dan Setyawan, 2015). Keanekaragaman hayati yang ada di dalam cagar alam memiliki manfaat bagi manusia maupun lingkungan. Keberadaan burung memiliki peran dalam menjaga lingkungan mulai dari rantai makanan, jaring-jaring makanan dan proses alami yang terjadi di lingkungannya. Berdasarkan hal tersebut dilakukan upaya dalam melestarikan lingkungan dan melakukan konservasi burung sangat dibutuhkan untuk melestarikan keberagaman jenisnya di alam (Nugroho dkk, 2015).

Keanekaragaman jenis burung di alam memiliki daya tarik khusus bagi peneliti maupun pengamat burung yaitu berasal dari keunikan dan keindahannya (Ahmad dkk, 2015). Keanakearagaman burung pada suatu kawasan dapat disebabkan oleh tipe habitat serta vegetasi tumbuhan yang ada pada kawasan tersebut. Pada beberapa tipe habitat burung memiliki perbedaan yang terlihat jelas yaitu banyak sedikitnya vegetasi yang tumbuh pada suatu lokasi dan jenis vegetasi yang tumbuh pada suatu kawasan dengan luasan tertentu (Susanto, 2012). Tipe habitat pada beberapa wilayah konservasi berupa suaka alam, cagar alam atau taman wisata alam memiliki kondisi habitat yang tidak jauh berbeda misalnya pada Cagar Alam yang terletak di Pangandaran Jawa
Barat memiliki tipe habitat hutan daratan rendah dengan jenis vegetasi yang hampir sama pada seluruh kawasan cagar alam (Safanah dkk., 2017). Menurut Chrystanto dkk. (2014) kawasan konservasi Cagar Alam Keling memiliki tiga tipe habitat yaitu habitat lahan basah berupa mangrove, habitat dengan vegetasi tumbuhan padang rumput dan habitat hutan alam sekunder. Perbedaan habitat pada kawasan cagar alam memiliki kekhasan pada flora maupun fauna yang hidup pada habitat tersebut.

Cagar Alam Besowo memiliki jenis vegetasi yang khas sehingga dapat mendukung kehidupan burung. Vegetasi pada suatu kawasan dapat menyebabkan perbedaan jenis burung yang terdapat di suatu kawasan. Penelitian ini bertujuan untuk mengevaluasi tingkat keanekaragaman dan menganalisis tingkat kelimpahan jenis burung, dan di kawasan Cagar Alam Besowo Gadungan Kediri sekitarnya, serta mengevaluasi daya dukung lingkungan kawasan tersebut dalam mendukung keberadaan burung.

\section{BAHAN DAN METODE}

Penelitian ini termasuk penelitian deskriptif dengan teknik observasi secara langsung. Pengamatan dilakukan tanggal 10 dan 11 Maret 2018, 17 dan 18 Maret 2018, 24 dan 25 Maret 2018, pada pagi dan sore hari pukul 07.00-10.00 WIB dan 14.00-17.00 WIB. Pengamatan dilakukan pada lima stasiun yaitu area pintu masuk cagar alam (Stasiun 1), area kebun kopi dan hutang lindung Perhutani Kediri (Stasiun 2), area hutan Pinus merkusii (Stasiun 3), area hutan lindung Perhutani Kediri (Stasiun 4) dan area terbuka dekat bukit kura-kura (Stasiun 5) (Gambar 1).

Teknik yang digunakan observasi lapangan dengan metode jalur transek. Jalur transek setiap stasiun sepanjang \pm 200 meter dengan titik pemberhentian setiap 50 meter, setiap titik pemberhentian dilakukan pengamatan selama \pm 5-7 menit sehingga total waktu pengamatan setiap stasiun \pm 20-24 menit. Sepanjang jalur transek diamati, dicatat dan difoto burung yang melintas, terbang, bertengger berdasarkan ciri morfologi dan jumlah yang dijumpai. Tim sampling terdiri atas lima orang dengan dua tugas yaitu dua peneliti mencatat dan mengukur faktor fisik (suhu, kelembapan dan kecerahan) tiga orang melakukan pengamatan burung. Pengamatan burung dilakukan menggunakan teropong Bushnell perbesaran 10x25 lensa 60-70 mm, kamera Canon 1200D dengan lensa tele 75-250 mm, kamera Prosumer Nikon P900 perbesaran 83x, Termohigrometer, Luxmeter, tali 
rafia, meteran gulung, alat tulis, lembar catatan dan buku panduan lapangan karangan Mckinnon dkk. (2010).

Data burung yang diperoleh dianalisis dengan menggunakan indeks keanekaragaman ShannonWiener (Odum, 1993), dengan rumus sebagai berikut.

$$
H=\sum \frac{n i}{N} \ln \frac{n i}{N}
$$

Keterangan: $\mathrm{H}^{\prime}=$ Indeks keanekaragaman Shannon; ni= Jumlah suatu jenis; $\mathrm{N}=$ jumlah seluruh jenis.

Kategori nilai indeks dari kenaekaragaman Shannon - Wiener (H') adalah sebagai berikut.

$\mathbf{H}^{\prime}<\mathbf{1 , 0}$ memiliki makna keanekaragamannya termasuk dalam kategori rendah, 1,0 $<$ H' $\leq \mathbf{3 , 3 2 2}$ memiliki makna keanekaragamannya termasuk dalam kategori sedang, dan H’> $\mathbf{3 , 3 2 2}$ memiliki makna keanekaragamannya termasuk dalam kategori tinggi.

Kelimpahan merupakan indikator yang berfungsi untuk mengetahui kepadatan individu dalam suatu kawasan dengan menggunakan rumus kelimpahan relatif (Sriyanto, 2013):

$$
D i=\frac{n i}{N} x 100 \%
$$

Keterangan:

Di adalah kelimpahan relatif (\%), ni adalah jumlah individu setiap jenis, dan $\mathbf{N}$ adalah jumlah total individu.

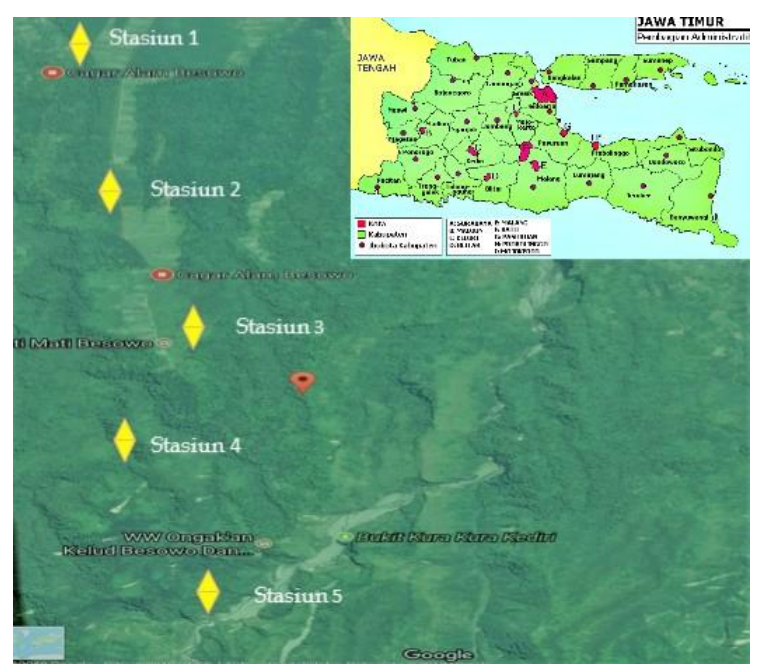

Gambar 1. Stasiun Penelitian

Keterangan: $\bigcirc$ Lokasi Cagar Alam Besowo Gadungan, Kabupaten Kediri.

Daya dukung lingkungan yang dianalisis adalah jenis vegetasi yang ada pada setiap stasiun dan pengukuran faktor fisik berupa suhu lingkungan, kelembaban dan kecerahan lingkungan.

Vegetasi dianalisis mengenai hubungan keberadaan vegetasi (pengaruh) tersebut terhadap kehadiran burung. Vegetasi diamati pada setiap stasiun dengan diidentifikasi kemudian dideskripsikan. Faktor fisik yang diukur berupa suhu lingkungan, kelembaban dan kecerahan lingkungan dianalisis berdasarkan hasil pengukuran yang didapatkan. Hasil pengukuran yang didapatkan dianalisis dengan menghubungkan nilai yang didapatkan kemudian dihubungkan dengan kehadiran burung.

\section{HASIL DAN PEMBAHASAN}

Berdasarkan hasil pengamatan di kawasan Cagar Besowo Gadungan dijumpai 38 jenis burung jenis burung terdiri atas sembilan Ordo antara lain Accipitriformes, Apodiformes, Columbiformes, Coraciiformes, Cuculiformes, Galliformes, Passeriformes, Piciformes dan Stigiformes. Famili yang ditemukan sebanyak 21 Famili. Di antara 38 jenis burung, terdapat lima jenis burung dengan status dilindungi berdasarkan Peraturan MENLHK Nomer 92 Tahun 2018 (Tabel 1). Data hasil pengamatan burung yang didapatkan teradapat perbedaan nilai indeks keanekaragaman pada setiap stasiun pengamatan. Stasiun satu hingga lima memiliki nilai keanekaragaman sebesar 2,47; 1,58; 2,23; 2,01 dan 1,71 (Tabel 2).

Nilai indeks keanekearagaman di Cagar Alam Besowo Gadungan sebesar 2,64 termasuk kategori sedang. Kelimpahan relatif yang didapatkan pada setiap stasiun memiliki persentase yang berbeda. Jenis burung yang paling banyak kemelimpahannya pada setiap stasiun adalah spesies walet linci (Collocalia linchi) dengan persentase kelimpahan sebesar 38,20\% dan cucak kutilang (Pycnonotus aurigaster) dengan persentase kelimpahan sebesar 10,11\% (Tabel 3).

Berdasarkan hasil pengukuran faktor fisik yang dilakukan selama enam kali pengamatan pada pagi dan sore hari didapatkan perbedaan suhu, kecerahan maupun kelembapan udara. Nilai rata-rata suhu seluruh stasiun pada pagi hari sebesar $28,9^{\circ} \mathrm{C}$, nilai kecerahannya sebesar 2279,68 Lux dan kelembapan udaranya memiliki nilai 56,23\%. Sedangkan rata-rata pengukuran fisik pada saat sore hari pada seluruh stasiun kisaran suhunya $25,9^{\circ} \mathrm{C}$, nilai kecerahan sebesar 1833,77 Lux dan kelembapan udara pada sore hari sebesar 60,97\% (Tabel 4).

Jenis tumbuhan yang tumbuh pada stasiun pengamatan antara lain Pohon Beringin (Ficus benjamina), Beringin Penkecik (Ficus annulata), Cengal Pasir (Hopea odorata), Kemiri (Aleurites moluccanus), Kopi (Coffea arabica), Pule (Alstonia scholaris), Pinus (Pinus merkusii), Rasamala (Altigia excelsa) dan Sengon (Albizia chinensis). Pohon 
beringin dan kemiri banyak dijumpai di Stasiun satu, pohon pule dan kopi dijumpai tumbuh pada Stasiun dua. Pohon cengal pasir dan rasamala banyak tumbuh di sekitar Stasiun empat dan lima. Pohon yang tumbuh pada Stasiun satu memiliki ciri kanopi yang lebar dan memiliki daun yang lebat. Akar dan batang besar dan kokoh. Stasiun satu dijumpai pohon beringin dan kemiri. Pohon pule memiliki batang yang besar dan kokoh namun kanopinya hanya lebat pada ujung batang. Pohon pule dijumpai tumbuh pada stasiun dua dengan tanaman kopi. Stasiun dua termasuk terbuka karena memiliki sedikit tumbuhan jenis pohon. Stasiun tiga dijumpai pohon pinus dengan beberapa pohon telah mati akibat letusan Gunung Kelud pada tahun 2014 lalu.

Tabel 1. Daftar burung yang dijumpai di Kawasan Cagar Alam Besowo Gadungan dan sekitarnya

\begin{tabular}{|c|c|c|c|c|c|}
\hline No & Ordo & Famili & Spesies & Nama Indonesia & Nama Inggris \\
\hline \multirow{3}{*}{1.} & \multirow[b]{2}{*}{ Accipitriformes } & \multirow{2}{*}{ Accipitridae } & Nisaetus bartelsi* & Elang jawa & Javan Hawk-Eagle \\
\hline & & & Spilornis cheela* & Elang-ular bido & $\begin{array}{l}\text { Crested Serpent } \\
\text { Eagle }\end{array}$ \\
\hline & \multirow{3}{*}{ Apodiformes } & \multirow{3}{*}{ Apodidae } & Collocalia linchi & Walet linchi & Cave Swiftlet \\
\hline \multirow[t]{2}{*}{2.} & & & $\begin{array}{l}\text { Aerodramus } \\
\text { maximus }\end{array}$ & $\begin{array}{l}\text { Walet-sarang } \\
\text { hitam }\end{array}$ & Black-nest Swiftlet \\
\hline & & & $\begin{array}{l}\text { Hemiprocne } \\
\text { longipennis }\end{array}$ & Tepekong jambul & $\begin{array}{l}\text { Grey-rumped } \\
\text { Treeswift }\end{array}$ \\
\hline \multirow{4}{*}{3.} & \multirow{4}{*}{ Columbiformes } & \multirow{4}{*}{ Columbidae } & Macropygia emiliana & Uncal buau & Ruddy Cuckoo-Dove \\
\hline & & & $\begin{array}{l}\text { Ptilinopus } \\
\text { melanospilus }\end{array}$ & Walik kembang & $\begin{array}{l}\text { Black-naped Fruit- } \\
\text { Dove }\end{array}$ \\
\hline & & & Streptopelia chinensis & Tekukur biasa & Spotted Dove \\
\hline & & & Treron griseicauda & Punai penganten & $\begin{array}{l}\text { Grey-cheeked Green- } \\
\text { Pigeon }\end{array}$ \\
\hline \multirow[b]{2}{*}{4.} & \multirow[b]{2}{*}{ Coraciiformes } & Alcedinidae & Todiramphus chloris & Cecakak sungai & Collared Kingfisher \\
\hline & & Meropidae & Merops leschenaulti & Kirik-kirik senja & $\begin{array}{l}\text { Chestnut-headed Bee- } \\
\text { eater }\end{array}$ \\
\hline \multirow{2}{*}{5.} & \multirow{2}{*}{ Cuculiformes } & \multirow{2}{*}{ Cuculidae } & $\begin{array}{l}\text { Centropus } \\
\text { bengalensis }\end{array}$ & $\begin{array}{l}\text { Bubut alang- } \\
\text { alang }\end{array}$ & Lesser Coucal \\
\hline & & & $\begin{array}{l}\text { Rhamphococcyx } \\
\text { curvirostris }\end{array}$ & Kadalan birah & $\begin{array}{l}\text { Chestnut-breasted } \\
\text { Malkoha }\end{array}$ \\
\hline \multirow[t]{3}{*}{6.} & \multirow[t]{3}{*}{ Galliformes } & \multirow[t]{2}{*}{ Phasianidae } & Gallus gallus & $\begin{array}{l}\text { Ayam hutan } \\
\text { merah }\end{array}$ & Red Junglefowl \\
\hline & & & Coturnix chinensis & Puyuh batu & Blue-breasted Quail \\
\hline & & Aegithina & Aegithina tiphia & Cipoh kacat & Common Iora \\
\hline \multirow{13}{*}{7.} & \multirow{13}{*}{ Passeriformes } & \multirow{2}{*}{ Campephagidae } & $\begin{array}{l}\text { Pericrocotus } \\
\text { cinnamomeus }\end{array}$ & Sepah kecil & Small Minivet \\
\hline & & & Coracina fimbriata & $\begin{array}{l}\text { Kepudang-sungu } \\
\text { kecil }\end{array}$ & Lesser Cuckooshrike \\
\hline & & \multirow[b]{2}{*}{ Cisticolidae } & Prinia inornata & Perenjak padi & Plain Prinia \\
\hline & & & Orthotomus sepium & Cinenen jawa & $\begin{array}{l}\text { Olive-backed } \\
\text { Tailorbird }\end{array}$ \\
\hline & & \multirow[t]{2}{*}{ Dicaediae } & Dicaeum trochileum & Cabai jawa & $\begin{array}{l}\text { Scarlet-headed } \\
\text { Flowerpecker }\end{array}$ \\
\hline & & & Dicrurus paradiseus & Srigunting batu & Greater Racket-tailed \\
\hline & & Monarchidae & Hypothymis azurea & Kehicap ranting & Black-naped Monarch \\
\hline & & Nectariniidae & $\begin{array}{l}\text { Anthreptes } \\
\text { malacensis }\end{array}$ & Madu kelapa & $\begin{array}{l}\text { Plain-throated } \\
\text { Sunbird }\end{array}$ \\
\hline & & & Cinnyris jugularis & Madu sriganti & Olive-backed Sunbird \\
\hline & & $P_{y c n}$ & $\begin{array}{l}\text { Pycnonotus } \\
\text { aurigaster }\end{array}$ & Cucak kutilang & Sooty-headed Bulbul \\
\hline & & Pycnonotiaae & $\begin{array}{l}\text { Pycnonotus goiavier } \\
\text { Pycnonotus plumosus }\end{array}$ & $\begin{array}{l}\text { Merbah terukcuk } \\
\text { Merbah belukar }\end{array}$ & $\begin{array}{l}\text { Yellow-vented Bulbul } \\
\text { Olive-winged Bulbul }\end{array}$ \\
\hline & & Rhipiduridae & Rhipidura javanica* & Kipasan belang & $\begin{array}{l}\text { Malaysian Pied } \\
\text { Fantail }\end{array}$ \\
\hline & & Sittidae & Sitta frontalis & Mungkuk beledu & Velvet-fronted \\
\hline
\end{tabular}




\begin{tabular}{|c|c|c|c|c|c|}
\hline No & Ordo & Famili & Spesies & Nama Indonesia & Nama Inggris \\
\hline \multirow{7}{*}{8.} & \multirow{7}{*}{ Piciformes } & Vangidae & $\begin{array}{l}\text { Hemipus } \\
\text { hirundinaceus }\end{array}$ & Jingjing batu & $\begin{array}{l}\text { Black-winged } \\
\text { Flycatcher-shrike }\end{array}$ \\
\hline & & Capitonidae & Psilopogon javensis* & $\begin{array}{l}\text { Takur tulung } \\
\text { tumpuk }\end{array}$ & Lineated Barbet \\
\hline & & \multirow[t]{2}{*}{ Picidae } & Dendrocopos analis & Caladi ulam & $\begin{array}{l}\text { Freckle-breasted } \\
\text { Woodpecker }\end{array}$ \\
\hline & & & Picoides moluccensis & Caladi tilik & $\begin{array}{l}\text { Sunda Pygmy } \\
\text { Woodpecker }\end{array}$ \\
\hline & & \multirow{3}{*}{ Rampastidae } & $\begin{array}{l}\text { Psilopogon } \\
\text { armillaris* }\end{array}$ & Takur tohtor & Flame-fronted Barbet \\
\hline & & & $\begin{array}{l}\text { Psilopogon } \\
\text { duvaucelii }\end{array}$ & Takur tenggeret & Blue-eared Barbet \\
\hline & & & $\begin{array}{l}\text { Psilopogon } \\
\text { haemacephalus }\end{array}$ & $\begin{array}{l}\text { Takur ungkut- } \\
\text { ungkut }\end{array}$ & Coppersmith Barbet \\
\hline 9. & Stigiformes & Strigidae & Strix leptogrammica & Kukuk beluk & Brown Wood-Owl \\
\hline
\end{tabular}

Keterangan: $(*)$ = Burung yang dilindungi berdasarkan UU No. P.92 MENLHK 2018.

Tabel 2. Indeks keanekaragaman dan kelimpahan jenis setiap stasiun pengamatan di Cagar Alam Besowo dan sekitarnya

\begin{tabular}{|c|c|c|c|c|c|c|}
\hline No & Stasiun & $\begin{array}{c}\text { Indeks } \\
\text { Keanekaragaman }\end{array}$ & Kategori & $\begin{array}{l}\text { Jumlah } \\
\text { Spesies }\end{array}$ & $\begin{array}{l}\text { Spesies Paling } \\
\text { Melimpah }\end{array}$ & $\begin{array}{c}\text { Spesies Paling Sedikit } \\
\text { Kelimpahannya }\end{array}$ \\
\hline 1 & 1 & 2,47 & Sedang & 26 & $\begin{array}{l}\text { Walet linci, Punai } \\
\text { penganten dan } \\
\text { Jingjing batu }\end{array}$ & $\begin{array}{l}\text { Cipoh kacat, Cinenen } \\
\text { jawa, Srigunting batu, }\end{array}$ \\
\hline 2 & 2 & 1,58 & Sedang & 12 & $\begin{array}{l}\text { Sepah kecil, } \\
\text { Walet linci dan } \\
\text { Takur tenggeret }\end{array}$ & $\begin{array}{l}\text { Walet-sarang hitam, } \\
\text { Tekukur biasa, } \\
\text { Jingjing batu }\end{array}$ \\
\hline 3 & 3 & 2,23 & Sedang & 18 & $\begin{array}{l}\text { Walet linci, } \\
\text { Caladi ulam dan } \\
\text { Sepah kecil }\end{array}$ & $\begin{array}{l}\text { Cekakak sungai, bubut } \\
\text { alang-alang dan } \\
\text { kepudang-sungu kecil }\end{array}$ \\
\hline 4 & 4 & 2,01 & Sedang & 14 & $\begin{array}{c}\text { Walet linci, } \\
\text { Walet-sarang } \\
\text { hitam dan uncal } \\
\text { buau }\end{array}$ & $\begin{array}{l}\text { Puyuh batu, sepah } \\
\text { kecil dan Punai } \\
\text { penganten }\end{array}$ \\
\hline 5 & 5 & 1,71 & Sedang & 9 & $\begin{array}{l}\text { Walet linci, } \\
\text { Cucak kutilang } \\
\text { dan Madu } \\
\text { sriganti }\end{array}$ & Elang jawa \\
\hline
\end{tabular}

Tabel 3. Keanekaragaman dan kelimpahan jenis burung di Kawasan Cagar Alam Besowo Gadungan dan sekitarnya.

\begin{tabular}{|c|c|c|c|c|c|c|}
\hline No & Spesies & $\begin{array}{l}\text { Jumlah } \\
\text { spesies }\end{array}$ & $\mathrm{ni} / \mathrm{N}$ & Ln ni/N & ni/N.Ln ni/N & Di (\%) \\
\hline 1 & Nisaetus bartelsi & 2 & 0,0032 & $-5,744605$ & $-0,018383$ & $0,32 \%$ \\
\hline 2 & Spilornis cheela & 4 & 0,064 & $-2,748872$ & $-0,175928$ & $6,40 \%$ \\
\hline 3 & Collocalia linchi & 238 & 0,382 & $-0,962335$ & $-0,367612$ & $38,20 \%$ \\
\hline 4 & $\begin{array}{l}\text { Aerodramus } \\
\text { maximus }\end{array}$ & 23 & 0,0369 & $-3,299544$ & $-0,121753$ & $3,69 \%$ \\
\hline 5 & Macropygia emiliana & 26 & 0,0417 & $-3,177254$ & $-0,132492$ & $4,17 \%$ \\
\hline 6 & $\begin{array}{l}\text { Ptilinopus } \\
\text { melanospilus }\end{array}$ & 3 & 0,0048 & $-5,339139$ & $-0,025628$ & $0,48 \%$ \\
\hline 7 & Streptopelia chinensis & 3 & 0,0048 & $-5,339139$ & $-0,025628$ & $0,48 \%$ \\
\hline 8 & Treron griseicauda & 15 & 0,0241 & $-3,725543$ & $-0,089786$ & $2,41 \%$ \\
\hline 9 & Todiramphus chloris & 2 & 0,0032 & $-5,744605$ & $-0,018383$ & $0,32 \%$ \\
\hline 10 & Merops leschenaulti & 11 & 0,0177 & $-4,034191$ & $-0,071405$ & $1,77 \%$ \\
\hline 11 & Centropus bengalensis & 1 & 0,0016 & $-6,437752$ & $-0,010300$ & $0,16 \%$ \\
\hline
\end{tabular}




\begin{tabular}{|c|c|c|c|c|c|c|}
\hline No & Spesies & $\begin{array}{l}\text { Jumlah } \\
\text { spesies }\end{array}$ & $\mathrm{ni} / \mathrm{N}$ & Ln ni/N & ni/N.Ln ni/N & $\operatorname{Di}(\%)$ \\
\hline 12 & $\begin{array}{l}\text { Rhamphococcyx } \\
\text { curvirostris }\end{array}$ & 14 & 0,0225 & $-3,794239$ & $-0,085370$ & $2,25 \%$ \\
\hline 13 & Gallus gallus & 1 & 0,0016 & $-6,437752$ & $-0,010300$ & $0,16 \%$ \\
\hline 14 & Coturnix chinensis & 5 & 0,008 & $-4,828314$ & $-0,038627$ & $0,80 \%$ \\
\hline 15 & Aegithina tiphia & 2 & 0,0032 & $-5,744605$ & $-0,018383$ & $0,32 \%$ \\
\hline 16 & $\begin{array}{l}\text { Pericrocotus } \\
\text { cinnamomeus }\end{array}$ & 35 & 0,0562 & $-2,878839$ & $-0,161791$ & $5,62 \%$ \\
\hline 17 & Coracina fimbriata & 1 & 0,0016 & $-6,437752$ & $-0,010300$ & $0,16 \%$ \\
\hline 18 & Prinia inornata & 12 & o,0193 & $-3,947650$ & $-0,076190$ & $1,93 \%$ \\
\hline 19 & Orthotomus sepium & 2 & 0,0032 & $-5,744605$ & $-0,018383$ & $0,32 \%$ \\
\hline 20 & Dicaeum trochileum & 7 & 0,0112 & $-4,491842$ & $-0,050309$ & $1,12 \%$ \\
\hline 21 & Dicrurus paradiseus & 1 & 0,0016 & $-6,437752$ & $-0,010300$ & $0,16 \%$ \\
\hline 22 & $\begin{array}{l}\text { Hemiprocne } \\
\text { longipennis }\end{array}$ & 1 & 0,0016 & $-6,437752$ & $-0,010300$ & $0,16 \%$ \\
\hline 23 & Hypothymis azurea & 1 & 0,0016 & $-6,437752$ & $-0,010300$ & $0,16 \%$ \\
\hline 24 & Anthreptes malacensis & 3 & 0,0048 & $-5,339139$ & $-0,025628$ & $0,48 \%$ \\
\hline 25 & Cinnyris jugularis & 16 & 0,0257 & $-3,661264$ & $-0,094095$ & $2,57 \%$ \\
\hline 26 & $\begin{array}{l}\text { Pycnonotus } \\
\text { aurigaster }\end{array}$ & 63 & 0,1011 & $-2,291645$ & $-0,231685$ & $10,11 \%$ \\
\hline 27 & Pycnonotus goiavier & 1 & 0,0016 & $-6,437752$ & $-0,010300$ & $0,16 \%$ \\
\hline 28 & Pycnonotus plumosus & 1 & 0,0016 & $-6,437752$ & $-0,010300$ & $0,16 \%$ \\
\hline 29 & Rhipidura javanica & 2 & 0,0032 & $-5,744605$ & $-0,018383$ & $0,32 \%$ \\
\hline 30 & Sitta frontalis & 4 & 0,0064 & $-5,051457$ & $-0,032329$ & $0,64 \%$ \\
\hline 31 & $\begin{array}{l}\text { Hemipus } \\
\text { hirundinaceus }\end{array}$ & 10 & 0,016 & $-4,135167$ & $-0,066163$ & $1,60 \%$ \\
\hline 32 & Psilopogon javensis & 1 & 0,0016 & $-6,437752$ & $-0,010300$ & $0,16 \%$ \\
\hline 33 & Dendrocopos analis & 32 & 0,0514 & $-2,968117$ & $-0,152561$ & $5,14 \%$ \\
\hline 34 & Picoides moluccensis & 12 & 0,0193 & $-3,947650$ & $-0,076190$ & $1,93 \%$ \\
\hline 35 & Psilopogon armillaris & 8 & 0,0128 & $-4,358310$ & $-0,055786$ & $1,28 \%$ \\
\hline 36 & $\begin{array}{l}\text { Psilopogon } \\
\text { duvaucelii }\end{array}$ & 28 & 0,0449 & $-3,103318$ & $-0,139339$ & $4,49 \%$ \\
\hline 37 & $\begin{array}{l}\text { Psilopogon } \\
\text { haemacephalus }\end{array}$ & 31 & 0,0498 & $-2,999740$ & $-0,149387$ & $4,98 \%$ \\
\hline 38 & Strix leptogrammica & 1 & 0,0016 & $-6,437752$ & $-0,010300$ & $0,16 \%$ \\
\hline
\end{tabular}

Keterangan: $\square$ Jenis burung yang paling banyak nilai kelimpahannya.

Tabel 4. Hasil rata-rata pengukuran faktor fisik seluruh stasiun

\begin{tabular}{llccc}
\hline No & Waktu Pengamatan & Suhu $\left({ }^{\mathbf{0}} \mathrm{C}\right)$ & Kecerahan (Lux) & Kelembapan Udara (\%) \\
\hline 1 & Pagi & 28,9 & 2279,68 & 56,23 \\
2 & Sore & 25,9 & 1833,77 & 60,97 \\
\hline
\end{tabular}

Berdasarkan hasil pengamatan yang telah dilakukan didapatkan 38 jenis burung yang terdiri atas sembilan Ordo, Famili yang ditemukan sebanyak 21 Famili. Burung yang ditemukan merupakan jenis burung hutan maupun burung arboreal namun ada dua jenis burung air yang ditemukan yaitu cekakak sungai dan kirik-kirik senja. Nilai indeks keanekeragaman di kawasan Cagar Alam Besowo dan sekitarnya menunjukkan bahwa jenis burung yang dijumpai tersebut beraktifitas, bertempat tinggal di kawasan tersebut.

Berdasarkan hasil perhitungan keanekaragaman jenis burung di kawasan Cagar Alam Besowo dan sekitarnya nilai keanekaragaman yang didapatkan adalah 2,64 termasuk kategori sedang. Nilai keanekaragaman sangat berkaitan dengan seberapa banyak jenis yang dijumpai pada stasiun pengamatan. Semakin banyak jenis yang ditemukan maka semakin tinggi nilai keanekaragaman yang didapatkan. Selain itu nilai keankeragaman yang tinggi dipengaruhi oleh faktor lingkungan bahwa ekosistem pada hutan tropis termasuk dalam ekosistem yang memliki kondisi stabil (Karim dkk., 2016). Setiap stasiun yang diamati memiliki nilai keanekaragaman yang berbeda hal ini disebabkan oleh tumbuhan yang hadir dalam suatu bentang lingkup habitat tersebut dan faktor lingkungan memiliki pengaruh besar untuk 
mendatangkan burung yang ada pada suatu lokasi (Rumanasari dkk, 2017).

Stasiun 1 nilai indeks keanekaragaman yang didapatkan 2,47, nilai tersebut termasuk kategori sedang. Jenis tanaman yang tumbuh di area ini adalah Pohon Kemiri (Aleurites moluccanus), Pohon Beringin (Ficus benjamina), Pohon Rasamala (Altingia excelsa), Beringin Pencecik (Ficus annulata). Stasiun ini termasuk dalam kategori yang cukup rimbun, sepanjang jalan dikelilingi oleh vegetasi berupa pohon dengan ukuran yang besar. Jenis burung yang dijumpai pada stasiun satu sebanyak 24 jenis dengan jenis terbanyak adalah jingjing batu, punai penganten dan wallet linci (Tabel 2 ).

Stasiun 2 dijumpai 12 jenis burung dengan nilai ideks keanekaragaman terendah dari pada stasiun lain yaitu 1,57 termasuk kategori sedang. Vegetasi yang dijumpai pada stasiun ini adalah kebun kopi (Coffea arabica) yang ditanam oleh warga sekitar lokasi stasiun. Area stasiun dua dinominasi oleh pohon-pohon yang tinggi dengan jarak yang cukup jauh sehingga stasiun ini cukup terbuka. Spesies yang ditemukan di stasiun ini termasuk dalam Famili Accripidae adalah elang jawa dan elang-ular bido. Elang jawa memiliki kebiasaan terbang secara soliter dan biasa terbang di daerah terbuka atau pegunungan sedangkan elang-ular bido memiliki kebiasaan bersoaring ketika terbang (Mac Kinnon dkk., 2010). Jenis lain yang dijumpai di stasiun ini adalah cucak kutilang, jingjing batu, sepah kecil, takur tohtor, takur tenggeret, tekukur biasa, puyuh batu, uncal buau, walet linci dan walet-sarang hitam.

Stasiun 3 dijumpai 17 jenis burung dengan nilai indeks keanekaragaman 2,23 termasuk kategori sedang. Stasiun ini terdapat satu jenis vegetasi yaitu Pinus merkusii. Kondisi Stasiun tiga memiliki vegetasi pohon dengan tajuk yang tidak rimbun sehingga termasuk dalam kawasan yang terbuka, sehingga dapat ditemukan jenis burung Famili Accripidae pada stasiun ini. Selain itu karena seluruh vegetasi yang ada pada stasiun ini memiliki batang pohon yang berkayu maka batang tersebut biasa digunakan oleh burung pelatuk untuk bersarang atau hanya sekedar bertengger.

Stasiun 4 merupakan stasiun dengan kondisi lingkungan yang cukup rimbun dengan jenis vegetasi yang tumbuh pada stasiun ini didominasi oleh pohon rasamala (Altingia excelsa) dan pohon cengal pasir (Hopea odorata). Jenis burung yang dijumpai di stasiun ini terdapat 14 jenis. Nilai indeks keanekaragaman yang diperoleh pada stasiun ini sebesar 2,01 termasuk kategori sedang. Jenis burung yang dijumpai pada stasiun ini antara lain cabai jawa, kadalan birah, takur tulung-tumpuk, punai penganten dan uncal buau.

Stasiun terakhir adalah stasiun 5 dengan vegetasi yang cukup jarang yaitu hanya ditemukan vegetasi jenis pohon rasamala dan cengal Pasir. Pada stasiun ini dijumpai elang jawa saat terbang kemudian bertengger. Lokasi ini termasuk terbuka dengan kanopi pada pohon tidak seluruhnya tertutup. Pada stasiun ini juga berdekatan dengan air terjun yang berasal dari Gunung Kelud sehingga dijumpai satu jenis burung air yaitu kiri-kirik senja. Vegetasi yang sering dijumpai adalah pohon rasamala sering digunakan untuk bertengger beberpa jenis burung passerine yang dijumpai misalnya Kadalan birah, Punai penganten, Uncal buau dan Walik kembang. Menurut Nainggolan dkk (2015) strutur vegetasi sangat mempengaruhi terbentuknya habitat burung yang berada di kawasan hutan. Struktur tajuk pada pohon yang membentuk kanopi juga dapat mempengaruhi kehadiran burung pada lingkungan tersebut.

Salah satu jenis pohon dengan kanopi sangat pendek serta memiliki batang tinggi dan berkayu adalah Pinus merkusii. Pohon Pinus merkusii yang dijumpai hanya pada stasiun tiga, jarak antar pohon cukup jauh sehingga dapat menarik perhatian burung jenis pelatuk untuk bersarang di pohon Pinus. Burung pelatuk sangat menyukai jenis pohon berkayu yang digunakan untuk membuat lubang dengan mematukkan paruhnya sehingga dapat dibuat sarang (Kusuma, 2017). Selain jenis burung pelatuk beberapa jenis lain sering bertengger di pohon pinus adalah cucak kutiang, cekakak sungai, cinenen jawa, kepudang-sungu kecil, punai penganten, munguk beledu, perenjak padi dan sepah kecil.

Pohon dengan struktur kanopi yang cukup lebat adalah pohon beringin dan pohon pule. Pohon beringin yang dijumpai memiliki akar yang menggantung (akar udara) serta memiliki batang kokoh dan kuat. Struktur tajuk pohon ini sangat lebat dan rimbun daunnya sehingga dapat digunakan untuk bersembunyi beberapa jenis burung yang sensitif terhadap kehadiran manusia. Burung kukuk beluk dijumpai bertengger pada pohon beringin sangat rimbun sehingga dapat menyembunyikan burung predator ini dari burung lain maupun mangsa yang diburunya (Prasetya dan Siswoyo, 2017).

\section{SIMPULAN}

Hasil penelitian menunjukkan bahwa Kawasan Cagar Alam Besowo Gadungan dan sekitarnya 
dijumpai 38 jenis terdapat 21 Famili dan sembilan Ordo. Keanaekaragaman pada kawasan ini termasuk dalam kategori sedang. Kelimpahan jenis yang dijumpai pada Kawasan Cagar Alam Besowo dan sekitarnya yaitu jenis walet linci (Collocalia linchi) $38,20 \%$, cucak kutilang (Pycnonotus aurigaster) 10,11\% dan Sepah kecil (Pericrocotus cinnamomeus) 5,62\%. Lingkungan pada kawasan Cagar Alam Besowo dan sekitarnya mendukung adanya keberadaan burung mulai dari aspek vegetasi yang dijumpai delapan jenis antara lain Albizia chinensis, Aleurites moluccanus, Alstonia scholaris, Altingia excelsa, Coffea arabica, Hopea odorata, Ficus annulata, Ficus benjamina danPinus merkusii. Faktor fisik yang mendukung kehadiran burung pada pagi hari hingga sore hari suhu rata-ratanya $25,9-28,9^{0} \mathrm{C}$; kecerahan sebesar 1833,77-2279,68 Lux dan kelembapan udaranya 56,23-60,97\%.

\section{UCAPAN TERIMA KASIH}

Terima kasih kepada BBKSDA Jatim untuk proses perizinan dan pendampingan selama pengambilan data berlangsung dan Teman-teman dari Kelompok Studi Srigunting Biologi Unesa yang telah membantu dalam proses pengambilan data.

\section{DAFTAR PUSTAKA}

Ahmad, Z., Sinyo, Y., Ahmad, H., Tamalene, M.N., Papuangan, N., Abdullah, A., Bahtiar \& Hasan S. (2017). Keanekaragaman Jenis Burung Di Beberapa Obyek Wisata Kota Ternate: Upaya Mengetahui dan Konservasi Habitat Burung Endemik. Jurnal Saintifika MIPA. 1 (1).

Anonim. (2018). Undang-Undang Republik Indonesia Nomor P.92 Tahun 2018 Tentang Jenis Tumbuhan dan Satwa yang Dilindungi, http://ksdae.menlhk.go.id/news/peraturan/P.922018-TSL-REV. Diakses pada tanggal 17 Oktober 2018.

BKSDA Jawa Timur. (2018). Cagar Alam Besowo Gadungan. http://bbksdajatim.org/ca-besowogadungan-1508/ Diakses pada tanggal 15 Januari 2018.

Chrysanto, S. Asiyatun, M.R. (2014). Keanekaragaman Jenis Avifauna Di Cagar Alam Keling II/III Kabupaten Jepara Jawa Tengah. Indonesian Journal of Conservation. 3 (1): 1-6.

Fitri, L.M., Handika, H., \& Solina, I.D. (2015). Burung Strata Bawah (Understory) Di Hutan Pegunungan Taman Nasional Kerinci Seblat (TNKS) Kerinci Jambi. Jurnal Saintek. 8 (1) 82-85.
Karim, N.H.A \& Hamzah, A.S. (2016). Keanekaragaman dan Status Konservasi Spesies Avifauna Pada Suazka Margasatwa Mampie, Kabupaten Polewali Mandar, Sulawesi Barat. Bioscientiae. 13 (1) : 1-10.

Kusuma, C \& Melyanti, R. (2017). Keragaman Komposisi Jenis dan Struktur Vegetasi Pada Kawasan Hutan Lindung dengan Pola PHBM di BKPH Tampomas, KPH Sumedang, Perum Perhutani Divisi Regional Jawa Barat dan Banten. Jurnal Silvikultur Tropika. 8 (2) : 123-129.

Mackinnon, J., Phillipps, K \& Balen, B.V. (2010). Panduan Lapangan Pengenalan Burung-burung di Sumatera, Jawa, Bali dan Kalimantan. Bogor: Burung Indonesia.

Nainggolan, F.H, Dewi, B.S \& Darmawan, A. (2015). "Keanekaragaman Jenis Burung: Studi Kasus Di Hutan Desa Cugung Kesatuan Pengelolaan Hutan Lindung Model Gunung Rajabasa Kabupaten Lampung Selatan”. Makalah disajikan dalam Seminar Nasional ङ Teknologi VI, Lampung, 3 November.

Nugroho, A.S., T. Anis, M. Ulfah. (2015). Analisis Keanekaragaman Jenis Tumbuhan Berbuah Di Hutan Lindung Surokonto, Kendal, Jawa Tegah dan Potensinya Sebagai Kawasan Konservasi Burung. PROS SEM NAS MASY BIODIV INDON. 1 (3): 472-476.

Odum. (1993). Ekologi Umum. New York : McGraw Hill. Prasetya, K.N \& Siswoyo, A. (2017). Burung-burung Taman Nasional Bromo Tengger Semeru. Balai Besar Taman Nasional Bromo Tengger Semeru. Penerbit Ediide Infografika: Malang.

Rumanasari, R.D., Saroyo \& Katili, D.Y. (2017). Biodiversitas Burung pada Beberapa Tipe Habitat di Kampus Universitas Sam Ratulangi. Jurnal MIPA Unsrat Online. 6 (1): 43-46.

Safanah, N.G., C.S. Nugraha, R. Partasasmita dan T. Husodo. (2017). Keanekaragaman Jenis Burung di Taman Wisata Alam dan Cagar Alam Pananjung Pangandaran Jawa Barat. PROS SEM NAS MASY BIODIV INDON. 3 (2): 266-272.

Sutarno dan Setyawan A.D. (2015). Biodiversitas Indonesia: Penurunan dan upaya pengelolaan untuk menjamin kemandirian bangsa. PROS SEM NAS MASY BIODIV INDON. 1(1): 1-13.

Sriyanto A, 2013. Perencanaan dan Perancangan Survey Keanekaragaman Hayati. Bandung: ICWRMIPCWMBC.

Susanto, A. (2012). Struktur Komposisi Vegetasi Kawasan Cagar Alam Manggis Gadungan. Agri-tek. 13 (2): 7887. 